\title{
The history of working animals in Africa
}

\author{
Paul Starkey \\ Centre for Agricultural Strategy, \\ University of Reading
}

\section{Introduction}

The employment of domestic animals for tillage or transport is known as animal traction. The term is generally understood to include pack transport as well as the 'pulling' work of animals. In various parts of the world cattle, buffaloes, yaks, horses, donkeys, mules, camels, llamas, elephants, reindeer, goats and dogs are used for transport, crop cultivation, water-raising, milling, logging and land excavation or levelling.

Cattle are the major work animals world-wide. It is most common to use male animals because they are stronger than females and cattle herds always produce a surplus of males. Castrated animals are more docile than intact males. Thus, the most common working cattle are castrated bulls, known as oxen or bullocks. In some texts, the word oxen has been used to describe any working cattle. Since working cattle are generally castrated males, the two uses of the word generally overlap. Nevertheless, confusion can occur in regions where cows or bulls are used for work. In this text, an ox is a castrated bull of any breed that is used for work. The term bovid encompasses the animals that are closely related to cattle, including water buffaloes and yaks.

After cattle, the main work animals world-wide are horses, donkeys (asses) and mules, known collectively as equids. In current English, a domestic ass is generally called a donkey. The word ass is now mainly confined to archaic, zoological or colloquial writings (and the statistics published by the Food and Agriculture Organisation). Mules are non-breeding hybrid animals formed by crossing a female horse with a male donkey. They are stronger than donkeys and more hardy than horses. The other possible cross (female donkey and male horse) is known as a hinney. These are much less common, partly because the cross is biologically much more difficult to produce.

This chapter explores the use and spread of animal traction in Africa from both chronological and geographical perspectives. However, since several different processes occurred in the continent, time sequences and country patterns will inevitably overlap. The study concludes by describing the present situation and current trends. As far as possible, references relate to information that is readily accessible: these are often review studies rather than primary sources.

\section{Origins and expansion}

The recorded history of animal power in Africa starts about 6-5000 bp in Egypt with the first drawings of oxen and ard plows occurring in the III Dynasty (Haudricourt and Delamarre, 1955). These, together with the engravings of oxen and plows in early Mesopotamian civilisations, appear to constitute some of the earliest records of animal traction anywhere in the world. It is possible that the maresha animal-drawn plow was spreading in Ethiopia at the same time as animal traction was developing in ancient Egypt, but there are fewer records from this period in Ethiopian history.

The early Egyptian ard plows were clearly illustrated in wall paintings and on papyrus. Further evidence comes from the intact plows that have been found in some tombs, and also from some detailed models of plowing teams. The plows comprised a long wooden beam, that pulled a horizontal wooden plow body fitted with a metal share. The plow was controlled by two handles. The ard plows widely used in Egypt to this day are not dissimilar to the ancient designs. The early drawings and models show animals plowing in yoked pairs. Some early illustrations suggest that the yokes were tied to the horns (head/horn yokes). Other illustrations and models suggest the use of withers yokes similar to those used in present-day Egypt.

Several ancient Egyptian illustrations clearly show that the animals used for plowing were cows. One possible historical and cultural explanation is that the ox was considered more sacred than the cow. In most parts of the world, oxen are the first bovids to be used for work. Cows only start to be employed when smallholder farming becomes intensive, when animal feed resources are limited and when the work operations are light or highly seasonal. These conditions may well have developed early in Egypt, particularly as equids were available for certain transport tasks (year-round work). In present-day Egypt, almost all animals used for plowing are cows.

Some ancient Egyptian illustrations show cattle pulling sledges. In the Papyrus of Ani (about 3300 years old), oxen are seen pulling the funeral sledge (Rossiter 1984). Wheeled ox-carts (as opposed to horse-drawn chariots) 
do not appear to have been common in ancient Egypt. Drawings and models of ox carts in nearby Mesopotamian civilisations date back about 5000 years ago.

Domestic donkeys were recorded at Maadi in Egypt 3500-4000 BP (Midant-Reynes, 1992). Paintings of pack donkeys appear in Egyptian tombs about 5000 years ago (Clutton-Brock, 1992). The main use of donkeys in ancient Egypt appears to have been for pack transport. Biblical evidence suggests donkeys were also important in the region for riding. Donkeys were not only maintained for work, for Cleopatra is said to have bathed in donkey milk.

The employment of horses in Egypt appears to have followed the use of donkeys. They do not appear until the about the $13^{\text {th }}$ Dynasty (about $3800 \mathrm{bp}$ ). Many Egyptian illustrations 3000-3500 bp show horses hitched in pairs for pulling two-wheeled chariots. A ceremonial chariot with light-weight spoked wheels was found in the tomb of Tutankhamun (3300 bp). Drawings dating from the same era show animals that appear to be mules or hinnies pulling two-wheel carts or chariots. However, there is no evidence that donkeys were used to pull carts in ancient Egypt (Clutton-Brock 1992).

\section{Animal traction in North Africa}

Archaeological evidence suggests that animal traction technology spread from ancient Egypt southwards into Sudan. The technology also spread around the Mediterranean, and it was probably widespread along the coast of North Africa by $500 \mathrm{BC}$. Animal traction has been an integral part of farming and transportation systems in north Africa for over 2000 years, and a wide range of species and technologies are now used. Camels are herded for meat, used for riding and pack transport and may assist with tillage operations or irrigation equipment. Horses are owned for riding, recreation and pulling carts, and some transport horses also assist with cultivation. Mules are mainly used for pulling carts and wagons in both urban and rural areas. They may also assist with soil tillage. Donkeys are mainly used as pack animals, and for riding. Donkey carts are found in urban and rural areas, and donkeys may also be expected to perform some soil cultivation work. While motorised transport has been increasing rapidly in the twentieth century, the use of animal power for local transport has not experienced a proportionate decline. However, long-distance transport of goods and humans using animals has been largely replaced by cars and lorries.

For the cultivation of heavy soils, notably in the irrigated fields along the Nile, cows remain the main type of working animal. Although ox-carts were used in North Africa in historic times, they are very rarely seen today. Animal-drawn carts in North Africa are almost invariably pulled by equids. Prior to the introduction of tractors in Morocco, some oxen were used for plowing. However, nowadays there is little economic justification for maintaining oxen that walk quite slowly and are relatively expensive to own. Plowing is now either performed by tractors or by other types of animals that have more uses during the rest of the year (horses, donkeys, mules, camels and cows).

Water buffaloes were probably introduced into Egypt around 1300 years ago (FAO, 1977). They have thrived and their numbers have grown so that their population in Egypt now equals that of cattle. Buffaloes are used for some plowing and water raising, but cows (with their superior tolerance of heat) remain the main plowing animals in Egypt. Water buffaloes have not spread in significant numbers from Egypt to other parts of Africa.

In the Maghreb region (Morocco, Algeria, Tunisia), pairs of animals tilling the land are almost invariably harnessed with an unusual belly-yoke system characteristic of this region. The belly yoke is a wooden bar suspended from straps around the withers (the beginning of the back) and which hangs under the chests of the two animals without touching them. The tillage implement is attached to the yoke. Historically, farmers plowed with long-beamed wooden ards, and these are still very widely used in the Maghreb. Short-beamed metal plows and cultivators have been slowly spreading during the twentieth century. Since the yoke is suspended a set height above the ground, it can be used to harness animals of different sizes and types. The same system is used to plow with two mules, two donkeys, a horse with a donkey, a cow with a donkey, a camel with a mule, or other unusual combinations.

Elephants were employed for military purposes in North Africa about 2300 years ago. They were used for ceremonial purposes prior to this, but their adoption as war animals around the Mediterranean followed the Asian battles of Alexander the Great. Hannibal of Carthage (in what is now Tunisia) remains world-famous for his attempts to deploy elephants against Rome. However, elephants were neither easy to manage during battles 
nor were they invincible. They were only deployed in military campaigns around the Mediterranean for about 300 years (Delort 1992) and thereafter reverted to a minor display role.

\section{Ethiopia and the Horn of Africa}

Ox-drawn plows appear to have been used in Ethiopia for at least two millennia, and possibly a much longer, although the origins of the maresha ard plow are not known. The single-handled Ethiopian scratch plow is very different in design from the two-handled plow used in Egypt. The maresha is more like a spear, pulled through the soil using a long beam. Goe (1987) reviewed several theories concerning its origins or introduction. Stiehler (1948) suggests the ard plow was introduced 2600-3000 years ago by Semitic-speaking peoples invading from South Arabia. Another view is that the plow was already in use at this time, having spread from Cushiticspeaking peoples of Nubia in northeast Sudan (Simoons 1965). Linguistic evidence suggests that the ard was in use 'several millennia' before the South Arabian invasion, which might make the Ethiopian plow the oldest in Africa (Ehret 1979). Drew (1954) illustrates rock paintings from Eritrea that clearly show a maresha plow, but their dating is uncertain.

The Ethiopian maresha is not only old, it is highly persistent. To the present day, it is almost universally used by smallholder farmers, for the cultivation of the tef grain crop. Although a variety of development programmes has attempted to introduce short-beamed steel plows for the past fifty years, there has been almost no adoption of these. The plowing animals are generally oxen, yoked in pairs with withers yokes, and controlled by a single person. Where oxen are in short supply, horses, donkeys or cows may be used, but oxen are the work animals of choice. Camels are occasionally used for cultivation. Ox-carts do not appear to have been part of Ethiopian traditional systems, and they remain extremely uncommon.

Transport of goods in Ethiopia has long been based on pack donkeys. Little is known about when donkeys started to be used in Ethiopia, and when they became common. Under the Pharaoh Pepi II (c. 2270 BC) caravans with pack donkeys were trading with Punt (Ethiopia) (Kitchen 1993). Donkeys have long been important in the history of the salt trade in northern Ethiopia (Wilson, 1976, 1991) and are represented in traditional Ethiopian art. The population of donkeys has been rising in recent history. With about five million donkeys, Ethiopia now has the second largest population of donkeys in the world. Pack donkeys are extremely important in both rural and urban economies. The success of military campaigns in Ethiopia and Eritrea in the late twentieth century owed much to the use of pack donkeys. Despite the large numbers of pack animals employed in Ethiopia, transport of loads by humans (mainly women) is still common.

Horses and mules are mainly used for riding. Simple passenger-carrying two-wheel horse-drawn carts became common in Ethiopian cities around the middle of the twentieth century. They were banned by the authorities from central Addis Ababa around 1963, but remain common in other towns. They are almost invariably used as passenger taxis for hire, and there is negligible use of horse carts for freight purposes.

Donkeys have not been traditionally used for pulling carts. However, an innovative design of low-cost donkey cart started to be seen in the Rift Valley of Ethiopia in the 1970s. In the rest of the world, most carts pulled by one donkey have parallel shafts that pass on either side of the animal. The donkey pulls from a collar or breast band, and the weight is taken by a band between the two shafts that passes over a back saddle. In contrast, the Ethiopian carts are pulled from converging shafts attached to a simple pack saddle. The carts made from wooden poles, with steel wheels, appear of recent, indigenous design, and have evolved in a country where donkeys have always been used to carry on their backs rather than pull from harnesses. At the end of the twentieth century, these carts have been spreading rapidly in the Rift Valley where they are used for the transport of water, straw and other materials. The development and rapid spread of these carts has been within the informal sector. It contrasts with the low uptake of the more expensive steel carts promoted by government agencies in the 1980s and 1990s.

\section{Stationary applications of animal power}

In Egypt there has been a long history of using work animals to raise water for irrigation. The ingenious sakia irrigation wheels appears to have been developed during the Ptolemaic period, about 2200 years ago (Stead 1986). The traditional sakia wheels have internal spirals, allowing them to efficiently raise water that is within two metres of the surface (Löwe 1986). They remain in use in present-day Egypt and may be turned by cows, buffaloes or donkeys or less commonly, horses or camels. 
Animals may also be used to pull water from wells. In North Africa, mote systems are employed, where an animal walks down a slope and pulls on the rope attached to a leather water bag (Löwe 1986). Some motes have self-emptying systems. Descending the slope makes it easier for the animal to raise the water. All types of work animals may be used. Elsewhere, notably in circum-Saharan Africa and the Horn of Africa, animals are also used to pull water from simple wells. Such systems are most common in pastoral areas, where large numbers of animals must be watered at the same time.

\section{Threshing}

Lagercrantz (1950) has reviewed the use of animals in Egypt, North Africa and Ethiopia and Northern Somalia for threshing. In this operation, the animals walk round in circles over beans or cereals, separating the husks from the grain. There is a strong geographical distinction between systems using a central tethering post and those which simply make use of random trampling movements. In Egypt, a special threshing sledge, no\#rag, may be pulled by the animals to accelerate the process. Pigs were used for work in Ancient Egypt, both treading and threshing seed in the eighteenth Dynasty, a practice also confirmed by Herodotos (Zeuner 1963:262). The first iconographic evidence for animal threshing is in the Old Kingdom (i.e. prior to $2300 \mathrm{BC}$ ) and this use of animal power has continued in Egypt up to the present.

Threshing is a seasonal operation and the species used are those that are readily available because they are maintained for other work. Iconographic evidence from Egypt suggests that donkeys were used in the Old Kingdom and were supplanted by oxen in the New Kingdom. Exceptionally, camels are used to thresh grain in Tunisia. In the Ethiopian highlands, oxen are used to thresh the cereal, tef. In the Ethiopian Rift Valley, a similar technology has more recently been adopted for decorticating maize.

Animal threshing occurs in both the Canaries and the Azores, probably as a result of European introductions. It was also brought to South Africa by European settlers, and Lagercrantz (1950:23) reproduces an early eighteenth century engraving of horse-threshing in the Cape Colony. Through the agency of missions, animal threshing spread to Namibia and to the Sotho-speaking areas.

\section{Milling}

Animal power is used for milling in a band stretching from Somalia to Chad. Oilseeds such as sesame or groundnuts are placed in a large wooden pestle, carved out of the trunk of a large tree. The animal walks around pulling a counter-balanced frame attached to a large wooden mortar. This grinds the seeds, extracting the oil. The animals employed are often oxen but camels may be used in Sudan and Somalia. This grinding technology is pre-colonial but its exact origin is unknown. The pattern of transfer of this animal-powered grinding technology has not been investigated. Similar mills are found in the Seychelles and on the Indian subcontinent, but they have not spread elsewhere in sub-Saharan Africa.

\section{Animal power for riding and pack transport in sub-Saharan Africa}

Horses, donkeys, camels and cattle have been used for riding and pack transport in parts of sub-Saharan Africa for centuries, if not millennia. However, relatively little is known about the history of these applications of animal power. Certain pastoralist groups in the continent, including several in West Africa, ride cattle and use them as pack animals. There are historical observations of fifteenth century European seafarers concerning the Khoi-Khoi of South Africa. These rode cattle and used them for pack transport. Some cattle were trained for use in battles (Burman, 1988; Joubert, 1995).

Equid remains have been found in archaeological sites in West Africa that date back over 2000 years (Blench 1993), but it appears that horses and donkeys were not widespread until about 1500 years ago. Several authors, including Muzzolini (1997), have noted that references to donkeys in traditional art (including rock paintings) and literature are surprisingly few in sub-Saharan Africa (including Ethiopian and Arabic sources). This might be because the spread of donkeys was slow and scattered, or it could be because donkeys had low status, compared with horses and camels. Donkeys were used mainly as pack animals (as they are world-wide) although there is little evidence to support this. By the time of recorded European exploration in sub-Saharan Africa, donkeys were used as pack animals in parts of West Africa (Sahelian zone) and East Africa (in some coastal ports and among the Maasai). A Portuguese report of 1758 suggests that the Shona in Zimbabwe were using pack donkeys, and this may have been associated with the gold trade route to and from Sofala in Mozambique (Ellert 1993). 
Horses became important for riding and prestige in West African civilisations across a wide zone of Musliminfluenced cultures from Senegambia to Sudan. Their high social status meant that they were seldom used for transporting goods. In Eastern and Southern Africa, horses were introduced from ports in the past five hundred years by European settlers and traders.

Camels, used for riding, transporting and meat/milk production spread in circum-Saharan countries between 1000 and 3000 years ago, first in the Horn of Africa and later in West-Central Africa (Banti 1993; Blench, this volume; Muzzolini, this volume). They are shown extensively in late period Saharan rock-paintings, but only as riding animals. Camels have probably been used to pull water from wells since their introduction, but their use for plowing in West Africa is recent (RIM, II 1992).

\section{Animal power for cultivation and wheeled transport in sub-Saharan Africa}

Ethiopia, together with a few neighbouring parts of the Horn of Africa, is exceptional in sub-Saharan Africa, since farmers have been using animal power for tillage for thousands of years. However, in most sub-Saharan African countries, animal traction for tillage and wheeled transport was introduced during the colonial period. The process of introduction and adaptation is still continuing.

There are various factors that may be responsible for the late adoption of plows in sub-Saharan Africa. In much of the continent, different tribal groups have specialised in animal-rearing and in crop production. Thus many crop-growing farmers did not own potential work animals. Moreover, many traditional farming systems have been based on bush-fallow rotations. The bush is cut down and burned, and seeds or tubers planted in the cleared area. There is no need to till the land with a plow. In any case this would be difficult since the soil is full of roots. Seeds can be scattered or planted in small pockets, for which a simple digging implement is appropriate. In farming systems with long periods of bush fallow, weeds do not present major problems. Provided the fallow periods are long, such systems can be quite productive in terms of yield per unit of human labour. It is only when human population pressures necessitate short fallow periods, that it becomes justified to clear the land of roots and stumps and to plow. Thus, in much of sub-Saharan Africa, the necessary social, environmental and agricultural conditions to favour the use of plows have not really existed. Indeed, there are still parts of Africa where the plow is not really economically justified. The failure of animal traction to spread into some semi-humid areas in recent decades, is partly explained by the lack of the appropriate preconditions (Starkey, 1986a and 1992; Pingali, Bigot and Binswanger, 1987).

Another important constraint on the spread of the plow in precolonial times was the presence of tsetse flies and trypanosomiasis in virtually all lowland areas. The relatively low human populations that obtained almost everywhere in Africa meant that hunting pressure on wild animal vectors was insufficient to eliminate reservoirs of trypanosomiases. Pastoral cattle that can survive when well-fed or moved regularly by expert herders have a much accelerated death rate from disease when subjected to work-stress (Blench 1987). It is possible that both wheeled vehicles and plows were introduced experimentally in prehistory, but failed due to disease constraints. Increased human population in the colonial era following improved health-care both allowed major clearance of regions of bush and eliminated large populations of tsetse vectors. This helped to make animal traction a viable proposition in many areas.

\section{African ports and islands}

Traders and colonial powers had contact with Africa's offshore islands and ports, before the hinterland was colonised. In most countries, the use of animal-powered wheeled transport was first introduced in coastal and river ports in the seventeenth, eighteenth or nineteenth centuries (Law 1980). In a few cases where social, economic and ecological conditions proved favourable, the use of animal-powered transport gradually spread from the coastal region, through the activities of traders, settlers, missionaries and the administering authorities. Animal-drawn cart technology spread inland in South Africa (and neighbouring territories), French West Africa (from Saint Louis) and in East Africa. However, with the notable exception of South Africa (and nearby countries), the introduction of animal power for agriculture was largely a twentieth century phenomenon.

When the Dutch settled in the Cape in 1652, they bartered goods for oxen and used these to pull carts. Ox carts transported goods to and from ships and building materials for the new settlement. Horses, mules and donkeys were imported within a few years and were also used for transporting people and goods. Although there are reports of settler farmers plowing with oxen as early as 1657, crop production was not a major activity of the early colonists. Hunting, trading and stock farming were more important. For these activities, the colonialists 
built four-wheel wooden wagons, pulled by large teams of oxen (ten was quite normal and sixteen were sometimes used). The semi-nomadic trekboers travelled widely in kakebeen wagons into the hinterland of the Cape in the seventeen and eighteenth centuries. They were followed by traders, missionaries and settlers, who also used ox wagons. In the nineteenth century, there were some major treks of settlers, including the Great Trek from 1836 to 1852 , from the Cape Colony through the Orange Free State to what became known as Transvaal and Natal. In 1874, some settlers took part in the long Dorsland Trek passing into what is now known as Botswana, Namibia and Angola (Burman 1988; Joubert 1995).

Behind the trekking settlers in Southern Africa, an infrastructure based on animal-powered transport was developed by miners, traders, missionaries and the administrative and military authorities. Horses were used for riding and military purposes. Prior to the development of railways, freight was generally moved by ox wagon. It has been estimated that in the first ten years of its development, 18,500 ox-drawn wagons entered Kimberley carrying supplies for the mines and its peoples (Joubert, 1995). In the nineteenth century, inter-town coach services were operated using horses and mules. One exceptional service in northern Transvaal used a mixed team of zebras and mules to pull its coach. Donkeys worked in the mines, and donkey carts were common for local transport. Following the outbreak of rinderpest in 1896, donkeys became important for a time for longdistance transport. Caravans of wagons, each pulled by 16-20 donkeys carried produce and goods in what is now Zimbabwe.

At the end of the nineteenth century, and in the early years of the twentieth century, animal power played a crucial role in the agricultural, mining and transport sectors of the growing economy of South Africa. Animals were used for urban and rural transport, they worked in the mines and they plowed for both large-scale (white) and small-scale farmers.

During the first half of the eighteenth century, horses were imported into Freetown (Sierra Leone) for riding, racing and wheeled transport (Dorward and Payne, 1975). In 1811, a Horse Tax was imposed, and modified to a Horse and Carriage Tax in 1828. However, an outbreak of a disease (thought to have been trypanosomiasis) in 1856 , severely restricted the subsequent use of horses. Although ox carts never fully replaced horses, they were used by the colonial authorities for port transport and some refuse collection (Starkey, 1981).

Horses had been used for riding in the semi-arid zone of West Africa for centuries before the European colonists arrived. The French established an important base in the port of St Louis (Senegal) and used horses and donkeys for transport in the port and town. Horses were also used by the military for expeditions into the hinterland, both for riding and for pulling artillery. However, horses did not thrive in the humid zone, and attempts to use horses for transport around Conakry (Guinea) had little success (Bigot 1989).

Madagascar has long been influenced by Asian cultures, where animal power has been long-established. One report (van Nhieu, 1982) suggested that animal traction was introduced into Mantasoa region during the regency of Queen Ranavalona 1 (1828-1861). This is broadly in line with the period of 1850-1880 mentioned by Bigot (1985). It is not clear whether animal power was used before this time. The animal-powered soil tillage implements in use in Madagascar today are steel plows, based on European designs of the industrial era. Had there been a long-standing use of animal power for soil tillage prior to the nineteenth century, one would expect to see some evidence of traditional long-beamed plows, such as those still widely used in North Africa, Ethiopia, the Middle East and South Asia. Although such implements do not appear to have been used, animal power was used for soil preparation in the rice fields. In the traditional piétinage system, cattle are made to walk round and round in rice fields, thereby creating a puddled soil suitable for rice cultivation. Wooden ox carts with large, spoked wheels became important for trade within the island in the nineteenth century, and such carts are still widely-used today. The technology for making wooden cart wheels was also established in Zanzibar and Pemba islands, although it does not seem to have transferred to the East African mainland.

Lamu island, off the Kenyan mainland, was for a long time an important Arab trading post, and pack donkeys were widely used for local transport. In the nineteenth century, European traders, explorers, settlers, military expeditions and missionaries set off to explore the mainland from a variety of bases on the east coast including Lamu, Pemba, Zanzibar, Tanga and Beira. Animal-drawn carts (generally ox-carts) were used for establishing forts, trading posts, settlements and mission stations. For example, staff of the London Missionary Society travelled through Tanzania by ox wagon in 1876-7 (Koponen, 1994, cited by Sosovele, 1997). Roads were constructed suitable for animal-drawn carts and wagons. By 1901, there were $1800 \mathrm{~km}$ of road suitable for ox 
wagons in and around Zambia (Müller, 1986). About the same time, ox wagons were moving from the coast (Tanga) to Arusha, and as far as Uganda (Sosovele, 1997). It seems probable that there were individual examples of early European traders, settlers and missionaries using animals for crop cultivation in East and Central Africa in the nineteenth century. However, the impact of such examples was small, for by the beginning of the twentieth century, animal traction was still largely absent from the agricultural systems in these countries.

\section{Sledges}

The origin and spread of the animal-pulled sledge in not clear. Simple triangular sledges are now very widely used throughout eastern and southern Africa and also in Madagascar. However, they are seldom, if ever, seen in West Africa, where they should be similarly useful as basic and cheap means of transporting materials. There is a wide range of sledge types and this suggests there has been considerable farmer innovation in the design of sledges. Three main types have been identified in Zambia, the dug-out log (umulangu), and the flatter carved board (mula) and the simple Y-branch (Müller, 1986). All of these, but particularly the Y-branch, may be modified with superstructures made from poles and/or basket work. There is some uncertainty as to whether or not the umulangu was in use in Zambia prior to the arrival of the traders and missionaries in the nineteenth century (Müller, 1986). However, despite the different sledge designs, they are almost always pulled in a similar way. Oxen are used in pairs (one or more pairs) to pull the sledges by means of a steel chain attached to a standard withers yoke. This suggests that the present system of pulling sledges has spread in post-colonial times.

While considering sledges, it is interesting to note that there are several independent twentieth century examples of sledges being developed into simple carts, using wheels made from tree-trunks. One such example in northeastern Zimbabwe appears to have been a farmer response to the banning of sledges by the colonial authorities (who feared that sledges accelerated erosion). Four-wheel, articulating carts were developed from Y-branch sledges using cross-sections of tree-trunks and simple wooden axles. Similar innovations have been seen in the Mbeya region of Tanzania.

\section{Colonial promotion of animal traction in agriculture}

During the first half of the twentieth century, the colonial authorities or agricultural production companies in several parts of sub-Saharan Africa, attempted to introduce animal traction for cultivation. The aim was to increase agricultural production in the colonies by teaching the indigenous population how to use work animals for plowing.

One of the early schemes took place in 1900 in the West African country of Togo, then under German control. In the hopes of increasing cotton production, a team of black American experts from Alabama were hired by the Berlin Colonial Economic Committee to introduce animal power for cultivation. Further attempts were made in Togo in 1908 (at Mango) and 1913 (at Tabligbo). Although the idea of animal traction was not totally rejected, there was little adoption in Togo at that time. Even with further attempts at introduction in the 1950s, there were probably fewer than 1000 plows in use at the time of independence in 1960 (Westneat, Klutse and Amegbeto, 1986).

The French colonial authorities in Guinea discussed the idea of using animal power in local farms in 1910 (Bigot, 1989). One aim was to increase agricultural production: at that time Guinea exported both groundnuts and rice. A pilot farm, ferme indigène, was established in 1914, in the Niger valley near Kankan. Indigenous N'dama oxen were trained and found to work well. By 1918, there were twelve farms, locally known as fermes de chefs. In 1919, a total of 105 hectares on these farms were plowed with animals, and several crops including groundnuts and rice were grown successfully using animal power. The pilot farm approach was changed to that of a major agricultural campaign to encourage smallholder farmers to grow crops using animal power. The campaign, which was started in 1924, was supported by adaptive research, including on-farm evaluation of a variety of implements. A wide range of support services was made available, including training schools, provision of equipment, credit and marketing. Plowing competitions were held. The number of farmers using animal power increased rapidly, and by $1929,15,000$ oxen had been trained and 24,000 ha were cultivated with animal power. The area plowed per team of animals increased in Haute Guinée from 3.55 ha to 5.05 ha. Guinea led the way in animal power in West Africa. In 1931, there were reported to be 5700 ox plows in Guinea, compared with 2000 plows and cultivators in the whole of the rest of Francophone West Africa, including what is now Benin, Burkina Faso, Côte d'Ivoire, Mali, Mauritania, Niger and Senegal. The very rapid growth in 
animal traction slowed in the 1930s as the policies and practices of the support services (notably credit and equipment provision) varied, and certain ecological limits to animal traction were noted (Bigot, 1989).

The humpless taurine N'dama oxen in Guinea were worked in pairs with simple yokes tied to the horns. In France, both head/horn yokes and withers yokes are used in different areas, and it may be that the officers responsible for the initial training of oxen came from a region in France where head/horn yokes were common. The fact that the animals were humpless should not have affected the choice of yoke, since European animals were also humpless. These were worked with withers yokes in parts of France and most of northern Europe and with horn/head yokes elsewhere in France and in Spain and Portugal. Whatever the original reason for the choice, horn/head yokes subsequently became standard for use with N'dama cattle in the countries surrounding Guinea (Côte d'Ivoire, Guinea Bissau, The Gambia, southern Mali, southern Senegal and Sierra Leone). Elsewhere in the region, Zebu cattle were worked with withers yokes. Withers yokes are now the norm throughout Africa, except in those countries around Guinea where to this day the taurine cattle continue to be worked with horn/head yokes.

Information concerning the success of the animal traction scheme in Guinea reached neighbouring Sierra Leone, then under British administration. In 1927, the British authorities banned a traditional form of domestic slavery practised by the Mandinka people. The Mandinka elders asked how they could cultivate their rice fields without their traditional labour supply. The Sierra Leone Department of Agriculture, based at Njala, had already experienced problems with the first few tractors introduced, and so suggested the use of animal power. This was a new and innovative technology in the farming systems of Sierra Leone, where human labour was the only power source. Three Sierra Leonean agricultural instructors were sent to Kankan in Guinea in 1928 to learn how to work with N'dama oxen. They returned and taught people to train animals and to plow. The Director of Agriculture "had great confidence the ox-plough had come to stay". In 1930, "all operations in connection with ox ploughing succeeded almost beyond expectations" and animal power training centres were established in four locations (Starkey 1981, 1982). The technology was adopted and slowly spread. Initially, Frenchmanufactured plows and harrows were purchased from Guinea, but later Ransome plows from Britain were imported. During animal power surveys in the 1980s, the first introduction of animals for plowing in 1928 was still fresh in the minds of the village elders. Moreover, some of the words still used in the training of the animals, appeared to have derived from the original French-language training (e.g., "Allez!" for "Move!"). One of the original agricultural instructors sent to Guinea reported that his great grandchildren were plowing his farm using oxen (Starkey, 1982).

Animal traction did not spread as fast in Sierra Leone as it did in Guinea. There were two main reasons for this. The area of introduction in Sierra Leone was on the southern margin of the main cattle zone in West Africa, where cattle were few and ecological conditions were not particularly favourable for the use of work oxen. Secondly, work oxen were being introduced for basic food production, and not for an export-orientated cash crop. Thus, there was little financial incentive on the part of the authorities or the private sector to provide the same level of back-up services (produce marketing, credit, supply of equipment, training, animal health care) that proved important in establishing animal traction in Guinea. Both the contemporary reports of the Department of Agriculture and interviews with farmers suggested that shortage of equipment and lack of a support programme restricted the speed of adoption. Although animal traction had been firmly established in Sierra Leone since 1928, its expansion was slow until there was further formal promotion. Promotional schemes in the 1950s and again in the 1980s led to further adoption, encouraged by support services such as equipment provision, credit and training (Starkey, 1981; Bangura, 1990; Starkey, 1994a).

The Gambia provides a later example of formal colonial extension combined with informal farmer innovation and diffusion. Prior to 1955 there was virtually no use of draft animals for crop cultivation in The Gambia. The colonial authorities introduced a very structured extension programme based on ox plowing schools (subsequently known a Mixed Farming or District Extension Centres). By 1960 there were 13 schools with 104 trainees, and by 1965 (the year of Independence), there were 24 schools, with 377 people receiving training. The programme continued into the post-independence era, so that between 1955 and 1975, animal traction was successfully introduced into most Gambian villages. However, while the extension services were only promoting the use of yoked pairs of oxen, an alternative draft animal technology based on single-harnessed equines (donkeys and horses) was diffusing informally from Senegal. By 1988 more donkeys than oxen were being used in The Gambia. For cultivation of sandy soils, low-power implements (scarifying tines and seeders) were being used more than the higher-draft ridgers and plows first promoted by the extension services. Donkeys 
were inexpensive animals that appeared to offer faster and more timely cultivation. The Gambia therefore illustrates the importance of two separate processes in the introduction of animal power. The formal introduction programme was deemed necessary since animal traction had not arisen spontaneously nor did it appear to have diffused in any significant way from Senegal or Guinea prior to 1955. There was also the major change in technology from oxen to donkeys that diffused at least as rapidly without any official promotion. This change involved very different systems of harnessing, implements and husbandry. Through the two processes of formal extension and informal diffusion, animal traction became a normal part of farming systems in The Gambia in the period of about one generation (Mettrick, 1978; Starkey, 1986b and 1988; Haswell, 1991).

In Uganda, colonial farmers and the British authorities introduced ox plows for cotton production in the Teso District (east) at the beginning of the twentieth century. Uptake was rapid, with a favourable combination of training centres, available animals and implements and a cash crop. A variety of implements were tested, including wooden implements from India. Eventually, the British Ransome plow was considered the most suitable. Following the success in Teso, the technology spread in neighbouring Lango district, where there were 68 plows in use in 1930. This increased to about 2500 in 1940, 10,000 in 1950 and 15,000 in 1960 (Kinsey, 1984).

In 1903, European farmers and traders started to settle in the Machakos District of Kenya. They used heavy plows that required teams of six animals. There was no formal promotion of animal traction, but plows were available from trading stores. Some local Kamba farmers apparently started using ox plows in 1910. By 1912, the District Commissioner had noted an increase in farm size and cash-crop production associated with the innovation. By 1933, there were 600 plows in use. The lighter Ransome Victory plow became available in the $1940 \mathrm{~s}$, and became the most popular implement. By the late 1950s, almost all farmers in the District were making use of animal power, through ownership or hire. This high rate of adoption had taken place as a result of private-sector sources of equipment and without any formal extension or credit programmes (Tiffen, Mortimore and Gichuki, 1994).

In Tanzania, some settler farmers around Arusha used oxen for plowing around the beginning of the twentieth century, but the need was not considered great since human labour was readily available. The German colonial authorities attempted to introduce ox plows in 1910, with the aim of increasing food exports from the colony. Plows and harrows were sent to all District Offices, but there was little uptake. Reasons for the lack of adoption of the plow included poor and limited promotion and lack of suitable animals in certain areas. In the 1920s, the British colonial authorities also attempted to introduce ox plows imported from Britain. Uptake was very localised, with most interest in Sukumaland where cotton was grown. In the 1930s, gold production in Mbeya District (south-west) stimulated a local market for food crops, which in turn stimulated interest in the use of ox plows for rice production. By 1945 there were about 700 plows in use in that region. In Tamine District, it is said that legislation requiring people to grow maize stimulated interest in ox plows in the 1940s. Through the middle decades of the twentieth century, animal traction spread slowly in several separate areas of Tanzania mainly through informal diffusion rather than active promotion. The flow of information was assisted by migrant workers, who would see animal power in one area, and try it in their own villages. Adoption was assisted by the widespread availability of plows which were commercially marketed by traders of Asian origin (Sosovele 1991, 1997; Koponen, 1994, cited by Sosovele, 1997).

Similar localised schemes to promote animal traction were initiated by the colonial authorities in many subSaharan African countries between 1900 and 1960. The success tended to be very localised, and associated with semi-arid areas where there was a clear market for produce. By the time of independence, there were still some countries and many administrative regions in which animal traction was very rare. 


\section{Post-independence promotion of animal traction}

Most sub-Saharan African countries achieved independence from the colonial authorities in the decade 1957-66 (1974-75 for the Portuguese colonies). In some countries, it was assumed that the rapid tractorisation seen in Europe in the previous decades would follow swiftly in Africa. For this reason, many Ministries of Agriculture placed initial emphasis on tractorisation. Following the failure of most smallholder tractor hire schemes of the 1960 s and 1970s, together with the increases in the oil price in the 1980s, animal traction became a major feature of development strategies in many countries in sub-Saharan Africa. Donor-supported development projects promoting animal traction became increasingly common from the mid 1970s to late 1980s. However, in a few areas, animal traction spread rapidly in the immediate post-independence period.

Senegal provides one of the most dramatic increases in the period immediately after independence in 1960 . In Senegal, horses and donkeys had been used in the ports and towns since the nineteenth century. In the early twentieth century, some of the transport horses were brought to work on pilot farms, pulling tine cultivators (houes) rather than plows. During the 1920s, the agricultural authorities concentrated on promoting the use of horses and tine cultivators to assist in the production of groundnuts as an export crop in the groundnut basin of Thiès. By 1930, there were 770 cultivators in use, compared with only 50 plows, 20 seeders and 10 agricultural carts (Bigot, 1989). In the 1950s, the agricultural authorities carried out much research on the use of animal power, testing many seeders suitable for use with groundnuts (Havard, 1986). The timeliness of planting after the first rains was critical, and horses could pull seeders rapidly to ensure maximal benefits. However, horses were common only in the north of the country, and were not readily available for farm work in the central Siné Saloum area nor in southern Casamance. There was therefore increasing research emphasis on the potential for using oxen, which were rarely worked in Senegal prior to the 1950s.

The Programme Agricole was launched in 1958 (the year Senegal achieved internal self-government). Several institutions were created to support farmers through credit, training, provision of animal traction implements and other farm inputs and the marketing of crop products. The programme ran until 1980, and led to the rapid adoption of animal traction technology. This is well illustrated by the numbers of implements acquired during this time. The numbers of animal-drawn tine cultivators increased from about 3000 in 1958 to 340,000 in 1980, a $10,000 \%$ increase. The numbers of seeders increased from 40,000 in 1958 to 310,000 in 1980. Carts (horse-, ox- and donkey-drawn) increased from 5000 to 140,000. Plows increased from 1000 to 65,000 (Havard and Faye, 1988). To help meet the demand for animal traction equipment a local factory was established by a group of French firms. Although the programme was highly successful, funds ran out in 1980, and the period of rapid growth ended. With the ending of the credit, sales dropped and the factory went bankrupt, although it was subsequently re-launched under a new name. However, the technology had been transferred to the rural population, and it remains in use to this day. The technology has been gradually spreading into new areas, for example, into the rice-production systems of the southern province of Casamance (Fall, 1990).

The promotion of animal traction in Senegal was associated with major research programmes. Initially these were based on on-station trials, notably at Bambey (Nourrissat, 1965). Subsequently, emphasis was placed on model farms and then on-farm investigations by farming systems research teams. Several of the technologies developed and promoted failed, including animal-drawn wheeled tool-carriers which were heavy multipurpose implements. Although credit was made available for these, they were not widely adopted (Bordet, 1988; Starkey, 1988). At the same time, some farmer-invented technologies spread, including the use of cows (females) for work in Siné Saloum (Lhoste, 1983).

A very rapid expansion of animal traction took place in southern Mali in the 1970s and 1980s. There had been some promotion of animal power in the French colonial period, resulting in about 8000 animal traction implements in use at the time of independence. There was then a major campaign to increase cotton production using work oxen. The donor-supported programme was initially implemented by the French CFDT (Compagnie Française pour le Développement des Fibres Textiles) and then by the national CMDT (Compagnie Malienne pour le Développement des Textiles). These provided a comprehensive package of inputs including extension, implements, seeds and fertilisers, credit, marketing and farming systems research. The growth was rapid, rising to about 50,000 implements in use in 1974, and 150,000 in 1988. In thirty years, animal traction technology had changed from being rare, to being the normal agricultural practice in southern Mali (Zerbo and Kantao, 1988; Traoré, 1989). 
A similar post-independence pattern of very rapid adoption of animal traction based on a cotton crop was seen in Chad. Although there were long-standing traditional systems of using animal power (packing, riding, milling) there appear to be no reports of cultivation with animal power prior to the 1950s. Promotion by government agencies started just before independence in 1960. At this time there were estimated to be only about 100 plows in use in the country. By 1966 there were 7000, and by 1990 this had risen to about 115,000. This rapid rate of adoption was assisted by credit (almost all plows were bought with credit), the provision of the necessary inputs and a market for cotton as a cash crop. The proximity of northern Cameroun may also have been important, for by the time the promotional scheme started, news of an earlier, successful campaign in that country had been widely circulated (BDPA, 1966; Starkey, 1993).

There were many other examples of rapid localised growth of animal traction in West Africa resulting from promotional schemes, for example, in the semi-arid cotton zones of Burkina Faso, northern Cameroun, Côte d'Ivoire and Guinea Bissau (Bonnet, Guibert, Robinet and Lhoste, 1989; Peltre-Wurtz and Steck, 1991; Starkey, 1991; Mahdavi, 1992).

As a result of the various public-sector initiatives and farmer-to-farmer diffusion, tillage with animal power had become part of the normal farming systems in most of semi-arid West Africa by the 1990s. The use of animaldrawn carts, pulled by oxen or donkeys also increased dramatically. In many places where the use of animal power for cultivation or cart transport had been non-existent or very limited prior to $1960,60-95 \%$ of the rural population were using draft animals by the 1990 .

Further south, in the more humid parts of West Africa, there were some other examples of promotional schemes in the 1970s and early 1980s that resulted in low adoption rates. Such disappointing schemes tended to be near the margin of the forested area, for example southern Guinea, Sierra Leone, Ghana, Togo and the North-western Province of Cameroun. This proved to be a marginal zone for animal traction at this stage. Some projects faced major problems with animal sickness, and mortality rates as high as $50 \%$ were cited. The de-stumping of land to allow plowing was a serious labour constraint, and one that did not always seem justified. Some projects blamed social constraints, such as lack of tradition of animal husbandry and unfamiliarity with cattle. This overlooked the fact that similar constraints were rapidly overcome elsewhere, provided animal traction was economically profitable, assisted by supporting services, including credit and animal health and a good market for crops grown (Munzinger, 1982; Starkey, 1986a).

The situation in the forest-cropland interface zone was changing quite rapidly in the last two decades of the twentieth century. The boundary of the semi-arid zone appeared to be moving southwards in West Africa, and deforestation was increasing in all zones. The ecological and disease balances appeared to changing. While the overall adoption of draft animals in the semi-humid zone was still low, compared with the semi-arid zone, animal traction was often increasing rapidly from a low base. For example, in the 1980s, numbers of draft cattle increased from 2000 to 38,000 in Côte d'Ivoire and 2000 to 12,000 in Togo (Westneat, Klutse and Amegbeto, 1988; Starkey, 1992).

In eastern and southern Africa, immediate post-colonial promotion of animal traction during the 1960s and 1970s involved mainly national Ministry of Agriculture extension services. At this time, while national agricultural engineering services were placing emphasis on the development of tractor hire services, some centres were established to develop new 'appropriate technology' implements and carts. Some centres were established by national Ministries, while others were developed by non-governmental organisations: few worked closely with the end-users and few produced implements that were adopted by farmers. By the 1980s, national 'top-down' extension programmes and services appeared to have limited impact, and there was increased emphasis on area-specific, donor-assisted development projects. Some integrated projects had specific animal traction components, some of which proved highly effective. By the 1990s, there was increasing emphasis on participatory and farming systems approaches and linking projects that were working on animal traction (networking).

In Tanzania, ox training centres were established throughout the country to promote animal traction in the 1960s, 1970s and 1980s. Little attempt was made to concentrate animal traction extension in areas of greatest potential. An appropriate technology centre was established and an ox-plow factory was opened in 1970. Animal traction continued to spread slowly in the country, mainly through farmer-to-farmer diffusion of knowledge. In the 1980s, donor-assisted projects with animal traction teams worked in several parts of the 
country including Mbeya, Tanga and Maswa, and attempted to identify and alleviate some of the constraints to the spread of animal traction, including the provision of credit, and the supply of implements, carts and animals (donkeys in Tanga region). In 1991, a national network was formed to link animal traction programmes in the country (Sosovele, 1991; Starkey and Mutagubya, 1992; Starkey and Grimm, 1994).

At the time of independence in 1964, animal traction in Zambia was mainly found in the Southern Province. During the colonial period, the spread of the use of ox plows had been assisted by several favourable conditions. The smallholder farmers who were cultivating crops in the good agricultural zone had a tradition of cattle ownership. Ox plows were well known, having been used on colonial farms since the beginning of the century. Plows and spare parts manufactured in what is now Zimbabwe were readily available through private sector stores. There was a market for produce along the line of rail. The technology had penetrated a little into some other areas, notably to the west and the east, probably through farmer and worker migration and/or the influence of various missions and traders. In the 1970s and 1980s, donor-supported integrated development projects in several regions started to actively introduce animal traction, through extension, credit and assistance with the provision of inputs. Some appropriate technology organisations developed and promoted woodenwheeled carts (which were largely rejected). In some areas, uptake of ox power was rapid, and one project in the northwest had particular success in introducing animal-powered transport by providing credit and a supply of ox carts. In the more humid areas, where few cattle were owned, uptake was low, and mortality among the cattle acquired from other regions was high. In 1985, a national animal draft power programme was launched. This helped co-ordinate animal traction work in the various projects, as well as related research, implement production and training activities (Starkey, Dibbits and Mwenya, 1991; Löffler, 1994).

\section{Current situation and trends}

As the twentieth century ends and the twenty-first begins, the historical processes continue, and animal traction in Africa continues to spread and to evolve. There are still many areas where animal traction is absent from farming systems. In certain mountainous regions, forest zones, very arid areas or where the animal disease challenge is high, animal power may never be considered appropriate. However, at the margins of these areas, animal traction is likely to spread. The adoption of the technology in new areas is likely to result from farmer migration, farmer-to-farmer contact and the activities of development programmes. Development programmes, whether governmental or non-governmental, have been shown to be particularly effective at introducing technology rapidly into new areas, through training (technical knowledge is often a limiting factor), credit, input supplies and marketing arrangements. The introduction of animal traction into new areas, can also be influenced by farmers migrating from areas of animal traction use. These on-going processes can be clearly seen in many countries where there are some areas of animal traction adoption and some regions where animal traction has never been used. For example, in Guinea, Ghana, Tanzania, Zaire and Zambia animal traction is spreading each year into villages where it has never been used before, through both project promotion and the movement of farmers.

While official extension services and projects have proved successful at introducing animal traction for the first time, they have been less successful at promoting 'improvements'. Many innovative implements and harnessing systems have been developed and promoted by government services in Africa with negligible acceptance and adoption by farmers. Although extension services are meant to train farmers how to adjust plows 'properly', the vast majority of plows in Africa are not adjusted and used according to conventional agricultural engineering wisdom. In contrast, many innovations that have spread, such as use of donkeys or cows, have done so despite the disapproval of extension services.

In those parts of the world with a long history of animal traction, including north Africa and Ethiopia, one person works with a team of animals. In areas of introduction, animals may not be well-trained in the initial years and farmers may lack confidence. Thus, immediately after the adoption of animal power, between two and four people may work with a single pair of animals. In much of sub-Saharan Africa, it is still common for at least three people (one may be a child) to work with animals that are plowing. There is a tendency for the numbers to decrease, and in areas where animals have long been worked, two is the most common number of people. A further decrease to one person is only rarely seen. This may be associated with the fact that most implements are pulled by chains, whereas in areas of traditional use, long-beamed implements are more common. 
When animal traction is first adopted, the animals are generally only used for primary soil tillage. The mechanisation of subsequent operations such as weeding may not follow for many years. Farmers are generally reluctant to allow their animals into fields with crops, lest they damage them. However, weeding is a labourintensive operation, and animal-powered weeding is becoming more common in most African countries. In countries and areas with long experience of animal power, including southern Mali, Senegal, South Africa and Zimbabwe, the majority of animal-using farmers now weed with animal power. In other areas, including much of Malawi, Tanzania and Zambia, only a minority (albeit an increasing one) use weeders. While the introduction of weeding technology has sometimes been associated with a specific extension programme, in several areas weeding appears to have developed as a result of farmer-innovation. For example, in the Machakos area of Kenya, farmers weed using their plows (Tiffen et al, 1994).

Oxen are generally used when animal traction is first adopted. This is logical when animals and feed resources are plentiful. Cattle herds produce surplus male animals and cows are mainly valued for their reproductive and milk-producing capacities. The use of cows may start when oxen are in short supply or expensive, when farming systems become more intensive, when animal feed resources are a limiting factor and/or when work operations are light or highly seasonal. Cows are used widely in Egypt and North Africa and an increasing use of work cows has been reported in Senegal, Zambia and Zimbabwe. Such innovations are generally farmer-led, and not the result of extension programmes (Lhoste, 1983; Starkey et al 1991; Starkey 1994b).

In most sub-Saharan African countries (with the notable exception of Senegal), oxen were promoted and used as the main work animals. Horses were of high status and expensive and in tropical Africa generally only thrived in highland areas. Donkeys were considered too weak to plow, and were mainly used for pack transport. However, the range of the donkey is spreading in much of Africa. This expansion has been associated with changing climatic and agro-ecological conditions, including droughts and deforestation. Donkeys are increasingly used for pulling carts, for which they are well-adapted. In many cases, they are taking over from oxen for cultivation. This is not generally because they are better than oxen, but they are cheaper and more able to survive in drought conditions. The donkey population in Sahelian West Africa increased three-fold in the last half of the twentieth century (ten-fold in Senegal and The Gambia). Similar high increases have also reported in some southern African countries such as Botswana and Lesotho. The trend to increasing donkey populations is seen almost everywhere in Africa, apart from some North African states. Donkeys have replaced oxen as the main work animals in The Gambia, and they are becoming increasingly important in Namibia, South Africa and Zimbabwe. The move from oxen to donkeys has generally been a farmer-led innovation, which has sometimes been ignored or actively discouraged by agricultural authorities (Starkey 1987, 1994c, 1995; Starkey and Starkey, 1997).

Animals are not only being used increasingly for tillage in sub-Saharan Africa, the transport role of animals is becoming more important. In much of Africa, head-loading has been the main means to transport for domestic water, fuelwood and market produce. In the majority of sub-Saharan African countries, animal-drawn carts are being used increasingly for trade, farm and domestic transport and local hire. In addition to within-village work, animal-drawn carts often deliver and distribute the produce and goods that are transported to and from towns by motor vehicles. There is a clear trend towards increasing use of motor vehicles for transport of people and goods in both rural and urban areas. However, evidence from the more urbanised areas of Africa (and elsewhere in the world) suggests that the number of motor vehicles can rise a very long way before there is any reduction in the use of animal-powered transport. The two systems can co-exist for a long time (provided legislation does not lead to the banning of animal transport). The implication is that the present overall growth in the use of animal transport in Africa will continue for the foreseeable future.

In some countries, including Zambia and Tanzania, the number of carts is still low compared with rural populations. Cart adoption appears limited by the low availability of carts (or components), their high cost and lack of credit. Elsewhere, including Namibia, Senegal and southern Mali animal-drawn carts (mainly donkey carts) have become quite common, and in some areas most rural households own carts. Mauritania provides an example of the rapid increase in animal-drawn carts. Carts were very rare at the time of independence in 1960, perhaps 1000 in the whole country. By 1996, this had increased to about 75,000, mostly donkey carts. This growth resulted not from promotional schemes, but from direct investment by farmers and transporters, dealing with local traders and artisans. This represented a private investment in 1996 terms of about fifteen million US dollars. The proximity of Mali and Senegal, where carts are manufactured, facilitated the adoption of carts (Starkey, 1996). 
Most work animals in Africa have been owned and controlled by men. Most of the promotional schemes of the twentieth century have been directed by and at men. Involvement of women with work animals has been small, with the notable exception of donkeys. In many countries, women use donkeys for pack transport, and sometimes for riding. In a few areas, including Tarime in Tanzania, it has become common for women to work with oxen. Elsewhere, it is still unusual, but the involvement of women with work animals is increasing in many countries. This is particularly so in those rural areas where men travel far to work in towns, leaving women as heads of household. The trend towards increasing direct involvement of women in animal traction is being assisted in some countries by promotional and credit schemes targeted on women.

In most of Africa, animal power is being used to replace or supplement human power. This trend is continuing in most of the continent. With so many agricultural and transport tasks performed by humans, there is much scope for continued expansion. In some sectors, animal power has been replaced by motor power. Longdistance transport by animals is now rare. Although there are still examples of caravans in the circum-Sahara countries and Ethiopia (where salt is transported by donkeys in Tigre), the trend is for motor vehicles to replace animals for long-distance transport. While some nomadic pastoralists still use animal power for transport, there is a trend towards sedentarisation. Donkeys have generally been replaced in the mining industry.

In countries where farmers can own large areas of land suitable for crop production, tractor power is tending to replace animal power for primary cultivation. This trend has been seen in the second half of the twentieth century in several countries with large-scale farmers, including Kenya, Morocco, South Africa and Zimbabwe. In those areas of Africa where agricultural land is privately owned, the pattern of tractor mechanisation has been similar to that of other parts of the world. Tractorisation has been associated with large and increasing farm sizes. In inhabited rural areas, as some farms grow increasingly large to ensure motorisation is profitable, other farming families give up their right to the land (through legislation, sale, bankruptcy or other means). The situation in South Africa illustrates the point, although the mechanisation processes were obviously influenced by the apartheid policies. At the end of the twentieth century, there were just 60,000 large-scale farming families (historically white farmers) that used tractor power, with economies of scale making tractor utilisation profitable. On less land, there were 1.2 million smallholder farming families (historically black farmers) that used a combination of human power, animal power and tractor power. The provision of tractor power to the smallholder sector, whether by government or private enterprise, tended to be capital depleting and economically unsustainable (Starkey, 1995).

The picture throughout the continent (and elsewhere in the world) appeared broadly similar. The use of tractors by smallholder farmers to grow normal, rainfed crops is economically unsustainable in many circumstances. It is not possible to predict the long-term future of mechanisation, due to unknown developments in the technology and changing socio-economic conditions. However, in the immediate, foreseeable future, animal power is unlikely to be rapidly replaced by tractor power in the smallholder sector. Animal power may be replaced by tractors where large land-holdings are possible and where people consider the economic cost of tractors to be justified for social reasons.

\section{Conclusions}

Animal power for transport and cultivation has been used in Africa for over 5000 years. Animal traction has been an integral part of farming systems in north Africa and Ethiopia for at least two millennia. The use of animals for riding and pack transport has a long history in many parts of Africa, although details of its origins and spread are not well understood. The use of animal power for wheeled transport and soil tillage does not appear to have spread in sub-Saharan Africa, prior to the 'contact' and colonial periods. In the past five hundred years, the use of animal-power for wheeled transport spread slowly from ports and colonial bases. The animaldrawn plow was introduced into South Africa by colonists in the seventeenth century, and it spread slowly to neighbouring territories. In most other sub-Saharan countries, it was introduced in the twentieth century by colonial authorities wishing to increase agricultural production. In most villages in Africa, animal-drawn plows were introduced in living memory. Many successful colonial and post-independence promotional schemes involved the provision of implements, training, credit and marketing channels. In circumstances where implements were readily available through private-sector traders, animal traction sometimes spread without any promotional schemes. Following the introduction of animal traction technology, many innovations were developed and spread through informal farmer-to-farmer processes. At the end of the twentieth century, animal 
traction was still spreading in most of sub-Saharan Africa, and appeared likely to continue to increase in the foreseeable future.

\section{References}

BDPA, 1966. La culture attelée et la modernisation rurale dans le sud du Chad. Bureau pour le Développement de la Production Agricole (BDPA), Paris, France. 251p.

Bangura A B, 1990. Constraints to the extension of draft animal technology in the farming systems of Sierra Leone. pp 324-327 in: Starkey P and Faye A (eds), Animal traction for agricultural development. Proceedings of the Third Regional Workshop of the West Africa Animal Traction Network, held 7-12 July 1988, Saly, Senegal. Technical Centre for Agricultural and Rural Co-operation (CTA), Ede-Wageningen, Netherlands. 475p. ISBN 92-9081-046-7.

Banti, Giorgio. 1993. Ancora sull'origine del cammello nel Corno d'Africa: osservazioni di un linguista. In Ethno, Lingua e Cultura, A. Belardi (ed.), 183-223. Roma: Calamo.

Bigot Y, 1985. Quelques aspects historiques des échecs et des succès de l'introduction et du développement de la traction animale en Afrique sub-Saharienne. Machinisme Agricole Tropical, 91: 4-10.

Bigot Y, 1989.Un siècle d'histoire d'une technologie agricole: la traction animale en Guinée. pp. 36-52 in: Raymond G, Bigot Y and Bordet D (eds), Economie de la mécanisation en région chaude. Actes du IX séminaire d'économie rurale, 12-16 Sep 1988, Montpellier, France. Centre de Coopération Internationale en Recherche Agronomique pour le Développement (CIRAD), Montpellier, France. 409p. ISBN 2-87614-026-8.

Blench, R. M. 1987. Social determinants of animal traction in Nigeria. Report to the Agricultural Research Unit of the World Bank.

Blench, R. M. 1993. Ethnographic and linguistic evidence for the prehistory of African ruminant livestock, horses and ponies. In The Archaeology of Africa. Food, Metals and Towns, T. Shaw, P. Sinclair, B. Andah and A. Okpoko (eds), 71-103. London: Routledge.

Blench R. M. 1995. A History of Domestic Animals in Northeastern Nigeria. Cahiers de Science Humaine, 31(1), 181-238. Paris: ORSTOM.

Blench R M, 1997. A history of donkeys, wild asses and mules in Africa. In Blench R.M. and MacDonald K.C. (eds): The origins and development of African livestock: archaeology, genetics, linguistics and ethnography. UCL Press, London, UK

Bonnet B, Guibert B, Robinet $\mathrm{O}$ and Lhoste P, 1989. Conduite, gestion des carrières et valorisation des boeufs de trait in zones cotonnières (Burkina Faso, Côte d'Ivoire et Mali). pp 132-152 in: Raymond G, Bigot Y and Bordet D (eds), Economie de la mécanisation en région chaude. Actes du IX séminarie d'économie rurale, 12-16 Sep 1988, Montpellier, France. Centre de Coopération Internationale en Recherche Agronomique pour le Développement (CIRAD), Montpellier, France. 409p. ISBN 287614-026-8

Bordet D, 1988. From research on animal-drawn implements to farmers' appropriation: successes and failures of development experience in Senegal. Paper 88:384. International Conference on Agricultural Engineering held 2-5 March 1988, Paris, France. 25p.

Brewer, D.J., Redford, D.B. and S. Redford. 1994. Domestic plants and animals: The Egyptian origins. Warminster: Aris and Phillips.

Burman J. 1988. Towards the far horizon. Human and Rousseau, Cape Town, South Africa.

Clutton-Brock J, 1992. Horse power: a history of the horse and the donkey in human societies. Harvard University Press, Cambridge, Massachusetts, USA. 192p. ISBN 0-674-40646-X

Delort R, 1992. The life and lore of the elephant. Thames and Hudson, London, UK.

Dorward D C and Payne A I, 1975. Deforestation, the decline of the horse and the spread of the tsetse fly and trypanosomiasis (nagana) in nineteenth century Sierra Leone. Journal of African History: 16(2): 239-256.

Drew, S.F. 1954. Notes from the Red Sea Hills. South African Archaeological Bulletin, 9:101-2.

Ehret C, 1979. On the antiquity of agriculture in Ethiopia. Journal of African History 20: 161-177.

Ellert, Henrik 1993. Rivers of gold. Gweru: Mambo press.

FAO, 1977. The water buffalo. Food and Agriculture Organisation of the United Nations (FAO), Rome, Italy. 283p.

Fall A, 1990. Adoption et principales contraintes à la diffusion des équipements de traction animale en Basse Casamance, Sénégal. pp 267-275 in: Starkey P and Faye A (eds), Animal traction for agricultural development. Proceedings of the Third Regional Workshop of the West Africa Animal Traction Network, held 7-12 July 1988, Saly, Senegal. Technical Centre for Agricultural and Rural Cooperation (CTA), Ede-Wageningen, Netherlands. 475p. ISBN 92-9081-046-7.

Goe M R, 1987. Animal traction on smallholder farms in the Ethiopian highlands. PhD Thesis (Cornell University), UMI Dissertation Information Service, Ann Arbor, Michigan, USA. 408p.

Havard M, 1986. Les conclusions des expérimentations (1950-1985) sur les semis en culture attelée des principales espèces cultivées. Document de Travail 1986:10. Département Systèmes et Transfert, ISRA, Dakar, Sénégal. 116p.

Havard M and Faye A, 1988. Eléments d'analyse de la situation actuelle de la culture attelée au Sénégal: perspectives d'études et de recherches. pp 241-252 in: Starkey P and Ndiamé F (eds), Animal power in farming systems. Proceedings of workshop held 19-26 Sept 1986, Freetown, Sierra Leone. German Appropriate Technology Exchange (GATE), GTZ, Eschborn, Germany. 363p. ISBN 3528-02047-4.

Haudricourt A G and Delamarre M J, 1955. L'homme et la charrue à travers le monde. Géographie Humaine No. 25, Gallimard, Paris, France. 506p. Republished 1986 by Manufacture, Lyon, France. 410p. ISBN 2-904638-79-2.

Haswell M, 1991. Population and change in a Gambian Rural Community, 1947-1987. pp 141-171 in: Haswell M and Hunt D (eds), Rural households in emerging societies. Berg, Oxford, UK. 261p. ISBN 0-85496-730-3.

Joubert B, 1995. An historical perspective on animal power use in South Africa. pp 125-138 in: Starkey P. (ed). Animal power in South Africa: empowering rural communities. Development Bank of Southern Africa, Gauteng, South Africa. 160p. ISBN 1-874878-67-6.

Kinsey B H, 1984. Equipment innovations in cotton-millet farming systems in Uganda. pp. 209-252 in: Ahmed I. and Kinsey B H (eds), Farm equipment innovations in Eastern and Central Southern Africa. Gower Publishing, Aldershot, UK. 345p. ISBN 0-566-00697-

Kitchen, K.A.. 1993. The land of Punt. In The Archaeology of Africa. Food, Metals and Towns, T. Shaw, P. Sinclair, B. Andah and A. Okpoko (eds), 587-608. London: Routledge.

Koponen J, 1994. Development for exploitation: German colonial policies in mainland Tanzania. Helsinki, Hamburg. 748p. 
Lagercrantz, Sture. 1950. Contributions to the Ethnology of Africa, Studia Ethnographica Upsaliensia, I. Lund: Håkan Ohlssons.

Law, R. 1980. Wheeled vehicles in Africa. Journal of African History.

Lhoste, P. 1983. Développement de la traction animale et évolution des systèmes pastoraux au Siné Saloum, Sénégal (1970-1981). Rev. Elev. Méd. vét. Pays trop., 36 (3): 291-300.

Löffler C, 1994. Transfer of animal traction technology to farmers in the North Western Province of Zambia. pp 354- 359 in: Starkey P, Mwenya E and Stares J (eds), Improving animal traction technology. Technical Centre for Agricultural and Rural Cooperation (CTA), Wageningen, The Netherlands. 490p. 92-9081-127-7.

Löwe P, 1986. Animal powered systems: an alternative approach to agricultural mechanization. Vieweg, for German Appropriate Technology Exchange (GATE), GTZ, Eschborn, Germany. 60p. ISBN 3-528-02023-7.

Mahdavi G, 1992. Development of animal traction in cotton areas of French-speaking African countries. pp 83-87 in: den Hartog G and van Huis J A (eds), The role of draught animals in rural development. Proceedings of an international seminar held 2-12 April 1990, Edinburgh, Scotland. Pudoc Scientific, Wageningen, The Netherlands. 233p. ISBN 90-220-1048-1.

Mettrick H, 1978. Oxenisation in The Gambia. Ministry of Overseas Development, London. 68p.

Midant-Reynes B, 1992. Préhistoire de l'Egypte: des premiers hommes aux premiers pharaons. A Colin, Paris, France.

Müller, H. 1986. Oxpower in Zambian agriculture and rural transport. Edition Herodot Socio-economic Studies in Rural Development No. 65, Rader Verlag, Aachen, Germany. 151p. ISBN 3-922868-40-1.

Munzinger P (ed), 1982. Animal traction in Africa. GTZ, Eschborn, Germany. 490p. ISBN 3-88085-133-6.

Muzzolini, Alfred. 1997. Livestock in Saharan rock art. In Blench R.M. and MacDonald K.C. (eds): The origins and development of African livestock: archaeology, genetics, linguistics and ethnography. UCL Press, London, UK

Nourrissat, P. 1965. La traction bovine au Sénégal. L'Agronomie Tropicale 9: 823-853

Peltre-Wurtz J and Steck B, 1991. Les charrues de la Bagoué: gestion paysanne d'une opération cotonière en Côte d'Ivoire. Orstom Editions, Paris, France. 304p. ISBN 2-7099-1026-8.

Phillipson, D.W. 1993. The antiquity of cultivation and herding in Ethiopia. In The Archaeology of Africa. Food, Metals and Towns, T. Shaw, P. Sinclair, B. Andah and A. Okpoko (eds), 344-357. London: Routledge.

Pingali P, Bigot Y and Binswanger H, 1987. Agricultural mechanisation and the evolution of farming systems in sub-Saharan Africa. World Bank in association with Johns Hopkins Press, Baltimore, Maryland, USA. 216p.

RIM 1992. National Livestock Resource Survey. [6 volumes] Abuja: Final report to Federal Department of Livestock and Pest Control Services, Federal Government of Nigeria.

Rossiter E, 1984. The book of the dead: papyri of Ani, Hunefer, Ahhai. Liber, Geneva, Switzerland. 120p.

Simoons F. J. 1965. Some questions on the economic prehistory of Ethiopia. Journal of African History 6(1):1-13.

Sosovele H, 1991. The development of animal traction in Tanzania: 1900-1980s. PhD Dissertation. University of Bremen, Germany. $352 \mathrm{p}$.

Sosovele H, 1997. The challenges of animal traction in Tanzania. Paper (12p) prepared for a workshop of the Animal Traction Network for Eastern and Southern Africa (ATNESA) on Meeting the challenges of animal traction held 4-8 December 1995, Karen, Kenya. (Proceedings in preparation).

Starkey P, 1981. Farming with work oxen in Sierra Leone. Ministry of Agriculture, Freetown, Sierra Leone. 88p.

Starkey P, 1982. N'dama cattle as draught animals. World Animal Review 42, 19-26.

Starkey P, 1986a. Draught animal power in Africa: priorities for development, research and liaison. Network Paper 14, Farming Systems Support Project, University of Florida, Gainesville, USA. 40p.

Starkey P, 1986b. Strengthening animal traction research and development in The Gambia through networking. Consultancy Mission Report and Annotated Bibliography on Animal Traction. Gambia Agricultural Research and Diversification Project (GARD), Banjul, The Gambia. 50p.

Starkey P, 1987. Brief donkey work. Ceres 20, 6: 37-40.

Starkey P, 1988. Perfected yet rejected: animal-drawn wheeled tool-carriers. Vieweg for German Appropriate Technology Exchange, GTZ, Eschborn, Germany. 161p. ISBN 3-528-02034-2.

Starkey P, 1991. Animal traction in Guiné-Bissau: status, trends and survey priorities. Report of a consultancy mission carried out from 22 February to 5 March 1991 in association with Pan Livestock Services, Reading University and Gaptec, Lisbon Technical University. Animal Traction Development, Reading, UK. 22p.

Starkey P, 1992. Changes in animal traction in Africa and Asia: implications for development. pp. 11-24 in: den Hartog G and van Huis $\mathrm{J}$ A (eds), The role of draught animals in rural development. Proceedings of an international seminar held 2-12 April 1990, Edinburgh, Scotland. Pudoc Scientific, Wageningen, The Netherlands. 233p.

Starkey P, 1993. La traction animale au Chad: politiques et approches. Oxfam, Oxford, UK. 65p.

Starkey P, 1994a. The transfer of animal traction technology: some lessons from Sierra Leone. pp. 306-317 in: Starkey P, Mwenya E and Stares J (eds), Improving animal traction technology. Technical Centre for Agricultural and Rural Cooperation (CTA), Wageningen, The Netherlands. 490p. 92-9081-127-7.

Starkey P, 1994b. A world-wide view of animal traction highlighting some key issues in eastern and southern Africa. pp. 66-81 in: Starkey P, Mwenya E and Stares J (eds), Improving animal traction technology. Technical Centre for Agricultural and Rural Cooperation (CTA), Wageningen, The Netherlands. 490p. 92-9081-127-7.

Starkey P, 1994c. Donkey utilisation in sub-Saharan Africa: recent changes and apparent needs. pp 289-302 in Bakkoury M and Prentis R A (eds) Working equines. Proceedings of second international colloquium held 20-22 April 1994, Rabat, Morocco. Actes Editions, Institut Agronomique et Veterinaire Hassan 1l, Rabat, Morocco. 412p. ISBN 9981-801-11-9.

Starkey P, 1995 (ed). Animal power in South Africa: empowering rural communities. Development Bank of Southern Africa, Gauteng, South Africa. 160p. ISBN 1-874878-67-6.

Starkey P, 1996. La traction animale en Mauritanie: situation et perspectives. Project SPFP/MAU/4051. Food and Agriculture Organization of the United Nations (FAO), Rome, Italy. 34p.

Starkey P and Grimm J, 1994. The introduction of animal traction in the Tanga Region, Tanzania. GTZ, Eschborn, Germany. 65p.

Starkey P and Mutagubya W, 1992. Animal traction in Tanzania: experience, trends and priorities. Ministry of Agriculture, Dar es Salaam, Tanzania and Natural Resources Institute, Chatham, UK. 51p. 
Starkey P and Starkey M, 1997. Regional and world trends in donkey populations. Paper prepared for workshop on Improving donkey utilisation and management held 4-9 May 1997, Debre Zeit, Ethiopia. Proceedings to be published by the Animal Traction Network for Eastern and Southern Africa (ATNESA), Harare, Zimbabwe.

Starkey P, Dibbits H and Mwenya E, 1991. Animal traction in Zambia: status, progress and trends. Ministry of Agriculture, Lusaka in association with IMAG-DLO, Wageningen, The Netherlands. 105p.

Stead M, 1986. Egyptian life. British Museum Publications, London, UK. 72p. ISBN 0-7141-2040-5.

Stiehler W, 1948. Studien zur Landwirtschafts und Siedlungsgeographie Aethipiens. Erdkunde 2: 257-282.

Tiffen M, Mortimore M and Gichuki F, 1994. More people, less erosion: environmental recovery in Kenya. African Centre for Technology Studies, Nairobi, Kenya. 323p. ISBN 9966-41-082-1.

Traoré M, 1989. Mécanisation agricole et integration agriculture-elevage dans le cadre du Projet Mali-Sud CMDT. pp 111-131 in: Raymond G, Bigot Y and Bordet D (eds), Economie de la mécanisation en région chaude. Actes du IX séminarie d'économie rurale, 12-16 Sep 1988, Montpellier, France. Centre de Coopération Internationale en Recherche Agronomique pour le Développement (CIRAD), Montpellier, France. 409p. ISBN 2-87614-026-8.

van Nhieu J T, 1982. Animal traction in Madagascar. pp. 427-449 in: Munzinger P (ed). Animal traction in Africa. GTZ, Eschborn, Germany. 490p.

Westneat A S, Klutse Aand Amegbeto K N, 1988. Features of animal traction adoption in Togo. pp 331-339 in: Starkey P and Ndiamé F (eds), Animal power in farming systems. Proceedings of workshop held 19-26 Sept 1986, Freetown, Sierra Leone. German Appropriate Technology Exchange (GATE), GTZ, Eschborn, Germany. 263p. ISBN 3-528-02047-4

Wilson R T, 1976. Some quantitative data on the Tigre salt trade from the early $19^{\text {th }}$ century to the present day. Annali Instituto University of the Orient, Napoli 36:157-164.

Wilson R T, 1991. Equines in Ethiopia. pp 33-47 in Fielding D. and Pearson R.A. (eds), Donkeys, mules and horses in tropical agricultural development. Proceedings of colloquium held 3-6 September 1990, Edinburgh, UK. Centre for Tropical Veterinary Medicine, University of Edinburgh, UK. 336p. ISBN 0907146066.

Zerbo D and Kantao A, 1988. Traction animale au Mali. pp 175-181 in: Starkey P and Ndiamé F (eds), Animal power in farming systems. Proceedings of workshop held 19-26 Sept 1986, Freetown, Sierra Leone. German Appropriate Technology Exchange (GATE), GTZ, Eschborn, Germany. 263p. ISBN 3-528-02047-4.

Zeuner, F.E. 1963. A History of Domesticated Animals. London: Hutchinson. 